\title{
PELUANG DAN TANTANGAN PERAN PEREMPUAN DI ERA REVOLUSI INDUSTRI 4.0
}

\author{
Ni Wayan Suarmini ${ }^{1}$, Siti Zahrok ${ }^{2,}$ Dyah Satya Yoga Agustin ${ }^{3}$ \\ 1,2,3, UPT PMK Sosial Humaniora, FBMT, Institut Teknologi Sepuluh Nopember \\ Email:mini.wayan@gmail.com
}

\begin{abstract}
ABSTRAK
Perempuan dan laki-laki memiliki kesetaraan, sehingga perempuan dan laki-laki mempunyai kesempatan, akses serta peluang yang sama sebagai sumber daya pembangunan. Kesetaraan merupakan target yang harus dicapai dalam tujuan pembangunan nasional jangka menengah dan jangka panjang maupun Millenium Development Goal (MDGs). Perempuan tidak hanya menjadi pengguna hasil pembangunan, namun juga ikut berperan melaksanakan dan berpartisipasi di segenap aspek pembangunan bangsa. Usaha-usaha pemerintah untuk meningkatkan kemampuan perempuan dengan cara pemberdayaan, yang mengandung arti meningkatkan kualitas dan peran perempuan disegala bidang pembanguan. Program kesetaraan gender yang mengintegrasikan gender dalam arus pembangunan menempatkan perempuan sebagai subyek pembangunan. Hal ini merupakan peluang bagi perempuan untuk berkiprah lebih luas dalam menunjukan potensi diri. Perempuan memiliki peran-peran yang strategis dalam mendorong pembagunan yakni sebagai manajer rumah tanngga, sebagai pelaku ekonomi dan sebagai perempuan karier. Tantangan yang dihadapi perempuan dalam melaksanakan perannya di era digital bagaimana mengubah pandangan permisif masyarakat dan praktek budaya yang membatasi kemajuan perempuan
\end{abstract}

Kata kunci: peluang, tantangan, peran perempuan dan pembangunan

Perempuan dan laki-laki memiliki kesetaraan, sehingga perempuan dan laki-laki mempunyai kesempatan, akses serta peluang yang sama sebagai sumber daya pembangunan. Kesetaraan merupakan target yang harus dicapai dalam tujuan pembangunan nasional jangka menengah dan jangka panjang maupun Millenium Development Goal (MDGs). Arah pembangunan pada revolusi industri keempat menuju pada ekonomi digital dan teknologi, membuat industri science, technology, engineering, dan mathematics (STEM) memiliki prospek yang menjanjikan. Secara tidak langsung system digital telah merubah pekerjaan manusia menjadi lebih cepat dan efesien.

Revolusi Industri 4.0 merupakan era yang diwarnai oleh kecerdasan buatan (artificial intelligence), era super komputer, rekayasa genetika, inovasi, dan perubahan cepat yang berdampak terhadap ekonomi, industri, pemerintahan, dan politik. Gejala ini diantaranya ditandai dengan banyaknya sumber informasi melalui media sosial, seperti youtube, Instagram, dan sebagainya. Hadirnya Revolusi Industri 4.0 seharusnya dapat dimanfaatkan dan dikelola dengan baik oleh kaum perempuan karena memiliki prospek yang menjanjikan bagi posisi perempuan sebagai bagian dari peradaban dunia. Berdasarkan uraian tersebut, tulisan ini ingin mengkaji peluang dan tantangan peran perempuan diera revolusi Industri 4.0, melalui analisis permasalahan bagaimana peran perempuan diera digital serta bagaimana peluang dan tantangan yang dihadapi peran perempuan.

Perkembangan ilmu pengetahuan dan teknologi membawa dampak pada peran perempuan yang semakin kompleks. Era Revolusi Industri 4.0 ditandai dengan pesatnya perkembangan teknologi 
informasi dan komunikasi (TIK). Melalui perkembangan teknologi informasi dan komunikasi ini pengambilan, penyebaran dan penyajian informasi dapat dilakukan secara cepat dan akurat. Pengaruh positif perkembangan teknologi informasi dan komunikasi terhadap segala aspek kehidupan manusia seperti mempermudah melakukan komunikasi dan mendapatkan informasi yang semakin luas, dapat mendorong pertumbuhan ekonomi serta dapat mengoptimalkan efisiensi tenaga kerja. Penguasaan teknologi informasi dan komunikasi memberikan peluang yang lebih luas untuk maju dan meningkatkan kualitas hidup. Perempuan sebagai partner dalam pembangunan dewasa ini harus meningkatkan kemampuannya disegala aspek termasuk dalam penguasaan teknologi informasi dan komunikasi. Pentingnya akses dan penggunaan teknologi informasi dan komunikasi bagi perempuan karena perempuan memiliki peran yang sangat strategis, sebagai ibu rumah tangga dan sekaligus juga memiliki peran dalam masyarakat. Menyadari hal tersebut dalam meningkatkan kemampuan peran perempuan dalam pembangunan pemerintah telah melaksanakan melalui pemberdayaan perempuan.

Lestari (2011), kesetaraan akses dan penguasaan teknologi informasi dan komunikasi bagi kaum perempuan dan laki-laki sudah menjadi perhatian tingkat global, isu gender dan teknologi informasi dan komunikasi telah dicantumkan sejak deklarasi Beijing 1995 yang merupakan hasil konferensi ke empat tentang perempuan. Demikian juga dalam program Sustainable Development Goals (SDGs) tentang kesetaraan gender menekankan peningkatan penggunaaan teknologi informasi dan komunikasi untuk pemberdayaan perempuan (Gaib \& Dkk, 2017).

Pengakuan terhadap kesetaraan antara perempuan dan laki-laki sudah menjadi issu global, namun kesenjangan akses dan penguasaan teknologi informasi dan komunikasi antara perempuan dan laki-laki masih cukup besar. Data dari International Telecommunication Union (ITU), menunjukan bahwa prosentase pengguna teknologi informasi dan komunikasi kaum perempuan masih lebih rendah dari laki-laki. Hafkinn dan Taggart (2001) faktor-faktor penghambat perempuan di negara berkembang dalam penguasaan teknologi informasi dan komunikasi adalah pendidikan, keaksaraan, bahasa, waktu, biaya, norma sosial dan budaya (Gaib \& Dkk, 2017). Hal ini berdampak pada tingkat partisipasi perempuan dalam pembangunan sangat kurang. Pandangan masyarakat yang masih memandang ranah kaum perempuan ada dalam keluarga, menjebak perempuan untuk tidak mengambil bagian pada pekerjaan di luar rumah. Tiap individu secara hakiki memiliki kemerdekaan dan kebebasan dan setara, mereka tidak boleh dibatasi oleh kondisi kelahiran (biologis) dan memiliki potensi yang tidak terbatas untuk berkembang.

Kesetaraan gender menjadi sorotan dalam rangka memajukan peran perempuan dalam pembangunan. Dilihat dari sudut pandang kemampuan secara intlektual laki-laki dan perempuan dalam kapasitas dan potensinya sama. Sehingga laki-laki dan perempuan dapat dipandang setara, sedangkan kalau dicermati kemampuan spesifik adalah kemampuan yang berbeda karena feminimnya sehingga kesetaraan itu menjadi tidak tepat, dalam hal ini kesetaraan itu kalau dipandang harus sama (50:50) maka tidak akan pernah terjadi kesetaraan, konsep kesetaraan ini mengindikasikan bahwa laki-laki dan perempuan harus mempunyai kapasitas, kesukaan dan kebutuhan yang sama, sehingga idealnya mereka harus meraih tingkat kesehatan, pendidikan, pendapatan, partisipasi politik yang sama pula. Secara implisit di sini tidak diakui adanya tidak sama antara laki-laki dan perempuan (Wibowo, 2011).

Berdasarkan semangat kesetaraan dewasa ini minat kaum perempuan untuk memperoleh gelar terkait industri sains, teknologi, engineering, dan matematik cukup besar, terbukti dari banyaknya minat perempuan untuk bisa belajar dijurusan-jurusan teknologi dan sains. Hal ini merupakan perkembangan yang positif bagi kaum perempuan untuk mengambil posisi strategis dalam pembangunan bangsa. Pendidikan memberi pengaruh signifikan terhadap kesenjangan antara perempuan dan laki-laki, hal ini terbukti dari hasil survei Asosiasi Penyelenggara Jasa Internet Indonesia (APJII) tahun 2016 menemukan venetrasi internet tertinggi ada pada kelompok mahasiswa 89,70\% dan pelajar 69,70\% (Gaib \& Dkk, 
2017). Hal ini berarti bahwa pendidikan dapat mempersempit kesenjangan antara perempuan dan lakilaki. Pemerataan pendidikan sangat diperlukan bagi seluruh masyarakat termasuk perempuan. Wajib belajar yang dicanangkan oleh pemerintah memberi peluang bagi kaum perempuan untuk mampu memberdayaakan dirinya sehingga dapat mengambil peran yang setrategis dalam pembangunan bangsa.

Peran strategis perempuan dalam pembangunan bangsa tidak bisa dipandang sebelah mata. Hubeis (1985) mengatakan, perempuan memegang peranan strategis yakni sebagai pekerja rumah tangga (mengatur rumah, membesarkan dan mengasuh anak), berperan sebagai pekerja transisi (bekerja dalam bidang usaha keluarga) dan sebagai pekerja diluar rumah tangga sebagai perempuan karier. Sesungguhnya perempuan memiliki potensi luar biasa yang dapat dimanfaatkan untuk kemajuan bangsa. Mendidik generasi penerus bangsa sebagai pemberi pendidkan yang pertama dan utama bagi anak-anaknya, sehingga perempuan perlu memiliki wawasan dan pengalaman yang luas di bidang teknologi informasi dan komunikasi agar dalam menjalankan perannya tersebut bisa secara optimal. Hal ini akan berdampak pada lahirnya generasi penerus bangsa yang cerdas dan memiliki hati nurani. Perempuan diera digital tidak cukup berkiprah hanya sebagai ibu rumah tangga, tertapi dituntut juga harus mampu berkiprah dalam usaha keluarga maupun di dunia karier. Peran teknologi informasi dan komunikasi dalam menjalankan tugas dalam keluarga dapat memberi wawasan dalam mendidik dan mngatur rumah tangga secara modern, dapat sebagai sarana untuk mencari cara menyelesaikan persoal-persoalan dalam mendidik anak dan mengurus rumah tangga. Dalam bidang sosial peran teknologi informasi dan komunikasi bagi perempuan dapat dijadikan sarana penting dalam pemberdayaan ekonomi, yang saat ini kegiatan ekonomi bisa dilakukan secara online. Disamping itu juga dapat mendorong lebih banyak kegiatan-kegiatan sosial kemasyarakatan dapat dilakukan.

Kemampuan individu untuk bisa mengakses informasi di era digital merupakan hal penting, termasuk bagi perempuan. aktivitas menulis di blog yang dilakukan oleh para perempuan/ibu di emak2blogger ruang untuk menyampaikan problematika, khususnya yang menjadi finalis Srikandi Blogger 2015, telah mereduksi keterbatasan perempuan dalam akses media digital (Widyastuti, Nuswantoro, \& Sidhi, 2016). Partisipasi perempuan saat ini tidak hanya sekedar menuntut persamaan hak, tetapi juga menyatakan fungsinya dan mempunyai arti bagi pembangunan dalam masyarakat Indonesia. Peran domestic perempuan sebagai ibu yang bertanggung jawab atas urusan rumah tangga termasuk membesarkan anak (Wibowo, 2011), dan mendidiknya untuk menjadi insan yang memiliki karakter humanis, sepertinya tidak bisa tergantikan. Keluarga merupakan pendidikan yang pertama dan utama. Saat ini masyarakat umumnya masih memandang urusan pendidikan dalam keluarga merupakan tanggung jawab perempuan. Sesungguhnya pendidikan dalam keluarga merupakan tanggung jawab bersama saling melengkapi antara ayah dan ibu sehingga anak tumbuh menjadi insan yang sehimbang antara emosi dan rasionalitasnya. Peran domestic perempuan begitu penting, hal ini menuntut perempuan untuk bisa membuka diri dan memiliki wawasan yang luas sehingga mampu mendidik dan memberikan wawasan pada anak. Perempuan diera digital harus mampu menyesuaikan diri dengan perkembangan ilmu pengetahuan dan teknologi dengan tidak melupakan nilai-nilai luhur yang merupakan nilai budaya Indonesia. Alat-alat rumah tangga sudah mengalami perubahan dari sistem manual menjadi sistem digital. Penggunaan teknologi juga sudah merambah pada anak-anak, sehingga membutuhkan pendampingan agar tumbuh kembangnya tidak mengalami permasalahan.

Kemajuan dalam bidang ekonomi dan pendidikan mempengaruhi perempuan mengambil peran transisi yakni sebagai tenaga kerja, anggota masyarakat dan manusia pembangunan (Wibowo, 2011), untuk menunjukan eksistensi dirinya. Perempuan berkualitas mampu menempatkan dirinya dalam peran yang sangat penting baik sebagai ibu dalam mendidik generasi masa depan, maupun dalam ranah publik termasuk di era Revolusi Industri 4.0. Menurut Badan Pusat Statistik (BPS), hanya ada 30 persen pekerja perempuan di bidang industri sains, teknologi, teknik, dan matematik. Padahal, Revolusi Industri 
4.0 merupakan era yang diwarnai kecerdasan buatan, era super komputer, rekayasa genetika, inovasi, dan perubahan cepat yang berdampak kepada ekonomi, industri, pemerintahan, dan politik. Gejala ini ditandai banyaknya sumber informasi melalui media sosial. Hadirnya Revolusi Industri 4.0 seharusnya dapat dimanfaatkan dan dikelola dengan baik oleh kaum perempuan karena memiliki prospek yang menjanjikan bagi posisi perempuan sebagai bagian dari peradaban dunia.

Walaupun revolusi industri 4.0 memiliki prospek yang menjanjikan, namun ada sejumlah tantangan yang dihadapi tenaga kerja profesional perempuan untuk bekerja di dunia industri. Penelitian Unesco 2015 menunjukkan rendahnya tingkat partisipasi pekerja perempuan di bidang industri, hal ini disebabkan oleh persepsi lingkungan kerja di industri merupakan domain pekerjaan laki-laki, yang melibatkan pekerjaan fisik dan tidak menarik bagi pekerja perempuan. Selain itu, masih belum banyak lulusan perempuan bidang itu yang mengejar karir bidang industri. Sebagian besar pekerja perempuan memilih untuk bekerja di bidang administrasi dan manajemen yang tidak terkait langsung dengan bidang keahlian mereka.

Dalam kesempatan yang sama, Nita Yudi, Wakil Ketua Umum Kadin Indonesia Bidang Pemberdayaan Perempuan, mengatakan peran perempuan dalam industri STEM ini masih kecil. Data dari BPS RI Susenas 2016 menunjukan ada kesenjangan antara laki-laki dan perempuan dalam mengakses internet. Kesenjangan ini disebabkan oleh rendahnya pendidikan kaum perempuan, sehingga menghambat literasi digital karena mengakses internet paling tidak membutuhkan pengetahuan literasi dan bahasa (Suwana dan Lily 2017) (Gaib \& Dkk, 2017). Walaupun demikian namun kedepannya Indonesia harus optimis melihat kondisi Indonesia tren perempuan mengambil jurusan science dan MIPA terus meningkat berdasarkan Kementerian riset, teknologi, dan pendidikan tinggi (Kemenristek Dikti). Dalam meningkatkan peran serta perempuan didunia industri, perempuan harus menyadari bahwa dunia industri mimiliki prosfek yang menjanjikan pada pekerja perempuan. Kaum perempuan pasti bisa dan perempuan harus mengubah mindsetnya bahwa dunia Industri ini sangat bermanfaat. Dalam agenda pembangunan berkelanjutan 2030 (sustainable Development Goals ) dipastikan masalah-masalah yang terjadi pada perempuan seperti diskriminasi gender, kekerasan seksual, eksploitasi dapat diakhiri (Rahmawati \& Lukitasari, 2017).

Usaha-usaha untuk menarik kaum perempuan terjun kedunia industri telah banyak dilakukan dari berbagai pihak. Kadin Indonesia bekerja sama dengan berbagai pihak untuk pelatihan dan pemberdayaan perempuan. Sujatmiko, Deputi Bidang Koordinasi Perlindungan Perempuan dan Anak Kemenko Bidang Pembangunan Manusia dan Kebudayaan, mengatakan pemerintah sudah berupaya dalam perlindungan perempuan dan anak. "Perempuan dan anak memiliki sesuatu yang strategis di masa depan," pemerintah juga berupaya mengeluarkan regulasi-regulasi yang pro perempuan termasuk perlindungan. Selain itu, pemerintah juga mendorong program terkait pemberdayaan perempuan. program-program yang inovatif. Upaya pemerintah dalam pemberdayaan perempuan diantaranya adalah program Coding Mum atau pelatihan bahasa pemograman dari Badan Ekonomi Kreatif yang diharapkan dapat memberikan peluang perempuan untuk bekerja paruh waktu sebagai programmer. Kementerian Perempuan dan Perlindungan Anak sebagai aktor utama dalam upaya pemberdayaan perempuan melakukan koordinasi dan kerjasama dengan berbagai kementerian terkait seperti kementerian Sosial dalam hal bantuan dana usaha untuk meningkatkan kualitas ekonomi, kementerian riset dan teknologi dalam hal revitalisasi pusat studi perempuan untuk melakukan reset terkait pembangunan daerah (The Development Cafe). Jika semua pihak berpartisipasi, perempuan Indonesia lebih berdaya termasuk didunia industri. perempuan harus membuka diri dan mau terus belajar mengikuti perubahan zaman. Kaum perempuan sebagai pendidik generasi penerus harus mampu berbuat banyak, agar menjadi generasi yang mampu bersaing di era global, beretika, dan membanggakan, baik bagi diri sendiri, keluarga, masyarakat, bangsa dan negara 
Masih banyak tantangan yang dihadapi pemerintah dalam upaya pemberdayaan perempuan untuk mencapai kesetaraan gender di Indonesia saat ini. Hal yang paling mendasar adalah bagaimana mengubah sikap permisif masyarakat dan praktek budaya yang membatasi kemajuan perempuan. Pendidikan salah satu cara untuk memperkecil kesenjangan anatara kaum perempuan dan laki-laki, melalui pendidikan perempuan akan mampu berkiprah didunia yang lebih luas untuk menunjukan potensi dirinya. Berdasarkan hasil survey Asosiasi Penyelenggara Jasa Internet Indonesia(APJII) penetrasi pengguna internet tertinggi ada pada kelompok mahasiswa 89,70\% (Gaib \& Dkk, 2017). Hal ini membuktikan bahwa semakin tinggi tingkat pendidkan maka kesenjangan antara laki-laki dan perempuan semakin sempit jaraknya.

Suwana dan Lily, 2017, menyatakan sebagian perempuan Indonesia pengguna Internet yang aktif, namun memiliki literasi digital yang rendah, hal ini disebabkan oleh latar belakang pendidikan yang rendah, kurangnya fasilitas, kurangnya pelatihan dan juga sangat besar pengaruh budaya patriarki (Gaib \& Dkk, 2017). Hambatan-hambatan seperti itu hendaknya bisa dirombak dengan menekankan pentingnya pendidikan pada kaum perempuan. Laki-laki dan perempuan sama-sama memiliki peran yang penting dalam perkembangan peradaban manusia dan bertanggung jawab terhadap perkembangan gerasi berikutnya dan masyarakat .

Pada kabinet kerja era 2014-2019 kementerian pemberdayaan perempuan dan perlindungan anak (KPPPA) diperkuat dengan Peraturan Presiden no. 59 tahun 2015, Peran perempuan dalam pembangunan dapat dimaksimalkan dengan meningkatkan kualitas hidup terutama akses terhadap fasilitas pendidikan, kesehatan dan hukum. Hal ini menunjukan bahwa pemerintah serius dalam melindungi dan memberdayaakan perempun (Rahmawati \& Lukitasari, 2017). Perempuan diberi jaminan untuk perluasan kesempatan berpartisipasi baik dalam dunia politik maupun untuk terlibat secara aktif dalam berbagai kegiatan terkait pembangunan nasional baik di lingkungan pemerintah pusat dan daerah, organisasi atau kelompok tertentu serta di lingkungan tempat tinggalnya. Dalam rangka memperbesar keterlibatan kaum perempuan dalam pembangunan bangsa sangat perlu diadakannya program-program pemberdayaan bagi masyarakat khususnya bagi kaum perempuan seperti pelatihan keterampilan, kewirausahaan/UMKM serta pemanfaatan teknologi mutakhir yang mencakup semua wilayah dan disesuaikan dengan karakteristik dan kebutuhan tiap wilayah. sehingga para perempuan dapat berperan sebagai mitra sejajar laki-laki dalam memberikan kontribusi positif untuk mewujudkan pembangunan nasional yang inklusif dan responsif gender.

\section{Kesimpulan}

Peran perempuan diera digital tidak cukup hanya berperan sebagai ibu rumah tangga (domestik) tetapi juga dituntut untuk mampu berperan diluar rumah seperti melakukan usaha keluarga maupun sebagai perempuan karier. Diera digital yang ditandai dengan tumbuhnya industri STIM, memberikan peluang besar bagi perempuan untuk berkiprah lebih luas, namun masih sedikit yang mampu memanfaatkan kesempatan ini. Perempuan memiliki peran yang sangat strategis dalam pembangunan, oleh karena itu dukungan berbagai pihak sangat diperlukan. Pemerintah telah melaksanakan program kesetaraan gender yang mengintegrasikan gender dalam arus pembangunan menempatkan perempuan sebagai subyek pembangunan. Tantangan yang dihadapi kaum perempuan dalam mengoptimalkan perannya dalam pembanguanan bagaimana mengubah sikap permisif masyarakat dan praktek budaya yang membatasi kemajuan perempuan. Disisi lain perempuan dituntut memiliki wawasan yang luas, cerdas dan melek teknologi.

\section{DAFTAR PUSTAKA}


Gaib, H., \& Dkk. (2017). Profil Perempuan Indonesia 2017. (Santosa Didiek, Ed.). Jakarta: KP3A.

Rahmawati, D. Nu., \& Lukitasari, I. (2017). Pembangunan Manusia Berbasis Gender 2017. (S. B. Widoyono \& Dkk, Eds.). jakarta: KP3A.

Wibowo, D. E. (2011). Peran Ganda Perempuan dan Kesetaraan Gender. Gender, 3(1), 356-364.

Widyastuti, D. A. R., Nuswantoro, R., \& Sidhi, T. P. (2016). Literasi Digital Pada Perempuan Pelaku Usaha. Jurnal ASPIKOM, 3(1), 1-15. 